\title{
Development of Silver Ion Doped Antibacterial Clays and Investigation of Their Antibacterial Activity
}

\author{
Filiz B. Karel, ${ }^{1}$ Ali S. Koparal, ${ }^{1}$ and Elif Kaynak ${ }^{2}$ \\ ${ }^{1}$ Department of Environmental Engineering, Anadolu University, 26555 Eskisehir, Turkey \\ ${ }^{2}$ Department of Chemical Engineering, Anadolu University, 26555 Eskisehir, Turkey \\ Correspondence should be addressed to Filiz B. Karel; fbayrakci@anadolu.edu.tr
}

Received 18 November 2014; Revised 29 January 2015; Accepted 2 February 2015

Academic Editor: Rong Wang

Copyright (c) 2015 Filiz B. Karel et al. This is an open access article distributed under the Creative Commons Attribution License, which permits unrestricted use, distribution, and reproduction in any medium, provided the original work is properly cited.

\begin{abstract}
Kaolinite, sepiolite, and clinoptilolite were used as carriers to develop antibacterial materials. The materials were enriched in sodium by ion exchange. Silver ion exchange by silver nitrate followed by phosphoric acid treatment enabled the controlled release of silver. The antibacterial function of the materials was investigated by halo test and the amount of silver released was investigated by energy dispersive X-ray spectroscopy. The enhanced antibacterial efficiency was obtained by minimizing the silver release which further provided longevity to the material and prevented the health risks posed by excess silver release.
\end{abstract}

\section{Introduction}

Antibacterial materials, thanks to their ability to inhibit the growth of bacteria, have promising features to be used in a wide range of applications varying from water treatment [1], biomedical products [2], cosmetics [3], and paints [4] to textiles [5]. Some metals such as silver, copper, and zinc have been known to have antibacterial effects. They may be anchored to inorganic carriers such as clays, zeolites, and other aluminosilicates in order to produce inorganic antibacterial materials which are more favorable than organic antibacterial materials in terms of chemical stability, thermal resistance, safety to user, long-lasting action period, and so forth, $[6,7]$. Ion exchange properties play an important role in the silver loading of clays. For instance, silver-clinoptilolite showed considerable superiority over zinc-clinoptilolite and copper clinoptilolite in terms of antibacterial activity due to the selectivity sequence of clinoptilolite $\left(\mathrm{Ag}^{+}>\mathrm{Na}^{+}>\mathrm{Zn}^{2+}>\right.$ $\left.\mathrm{Cu}^{2+}\right)[8]$.

Silver presents bactericidal activity in its oxidized state, represented as $\mathrm{Ag}^{+}$; therefore soluble silver salts have long been used to inhibit the growth of bacteria [9]. Several mechanisms have been proposed in order to explain the inhibitory effects of $\mathrm{Ag}^{+}$on bacteria. Due to the high affinity of monovalent silver ions to sulfhydryl (S-H) groups, stable
-S- Ag bonds are formed which inhibit the hydrogen transfer and prevent the respiration and electron transfer [10]. It was shown that $\mathrm{Ag}^{+}$binds to functional groups of proteins and causes protein denaturation. Furthermore $\mathrm{Ag}^{+}$interaction may prevent DNA replication [11]. The bactericidal effects of silver ions loaded on nanoporous materials such as zeolites have also been attributed to ROS (reactive oxygen species) generation in deionized water systems and under short contact time conditions $[12,13]$.

Recently, there have been concerns about the implications of excessive use of silver in consumer products in terms of environment and human health. The accumulation of metallic silver under skin resulting from the overexposure to colloidal silver or silver salts was reported to cause skin diseases such as argyria or argyrosis [14]. Therefore, controlled release of $\mathrm{Ag}^{+}$must be ensured for its safe use in antibacterial products. In this study the controlled release of silver from the antibacterial material was provided using a novel methodology developed for the antibacterial functionalization of materials by the authors. Kaolinite, sepiolite, and clinoptilolite were modified by ion exchange and the controlled release was provided by subsequent phosphatisation. Hence, efficient antibacterial activity was provided by minimizing the risks that may be posed by the excess release of silver. The halo test procedure was applied to determine 
TABLE 1: EDX analysis results of the physically treated clays.

\begin{tabular}{lccccc}
\hline Carrier & $\begin{array}{c}\mathrm{O} \\
(\mathrm{wt} \%)\end{array}$ & $\begin{array}{c}\mathrm{Si} \\
(\mathrm{wt} \%)\end{array}$ & $\begin{array}{c}\mathrm{Al} \\
(\mathrm{wt} \%)\end{array}$ & $\begin{array}{c}\mathrm{Mg} \\
(\mathrm{wt} \%)\end{array}$ & $\begin{array}{c}\text { Others (i.e., } \mathrm{Ag} \text { * }, \mathrm{Fe}, \mathrm{Na}, \text { and Ca) } \\
(\mathrm{wt} \%)\end{array}$ \\
\hline Kaolinite & 60.36 & 17.50 & 16.01 & - & 6.14 \\
Clinoptilolite & 61.90 & 25.41 & 5.40 & 0.2 & 7.09 \\
Sepiolite & 55.44 & 16.74 & 0.14 & 17.49 & 10.33 \\
\hline
\end{tabular}

${ }^{*}$ Detailed analysis results are tabulated in Table 2.

TABLE 2: Amount of silver incorporated into clays by physical and chemical treatments.

\begin{tabular}{lcccc}
\hline \multirow{2}{*}{ Carrier } & \multicolumn{2}{c}{ Physical treatment } & \multicolumn{2}{c}{ Chemical treatment } \\
& Weight \% & Atomic $\%$ & Weight \% & Atomic \% \\
\hline Kaolinite & 0.13 & 0.02 & 0.84 & 0.15 \\
Clinoptilolite & 0.65 & 0.11 & 0.70 & 0.13 \\
Sepiolite & 0.75 & 0.12 & 0.79 & 0.14 \\
\hline
\end{tabular}

the antibacterial activities of the materials on Escherichia coli bacteria.

\section{Materials and Methods}

Kaolinite, clinoptilolite, and sepiolite clay samples collected from Eskisehir region were subjected to physical and chemical treatments which were explained in detail in this section. Following such treatments the antibacterial activities of the clays were tested by halo method and the silver release from the samples exposed to water media was also investigated.

2.1. Antibacterial Functionalization of Natural Clays. The clays were enriched in sodium by continuously stirring 10 grams of sample in $1 \mathrm{M}, 100 \mathrm{~mL}$ sodium chloride (Merck) solution for 24 hours, in order to increase the ion exchange capacity. The samples were then washed with distilled water and dried at $80^{\circ} \mathrm{C}$ for 1 hour. The silver ion exchange was performed by continuously stirring 10 grams of sample in $0.01 \mathrm{M}, 100 \mathrm{~mL}$ silver nitrate (Merck) solution at a dark environment. The physical treatment of clays was therefore completed. For the chemical treatment the materials were subsequently subjected to $0.1 \mathrm{M}$ phosphoric acid solution. The metal ion percentages of antibacterial functionalized kaolinite, sepiolite, and clinoptilolite were analyzed by energy dispersive X-ray spectroscopy (EDX Oxford Instruments and Zeiss EVO 50).

2.2. Determination of Antibacterial Activity. A modified version of the halo test method described elsewhere [15] was used for the determination of antibacterial efficiency of the material. The halo test was performed by placing a specific amount of material at the center of the sterilized petri dish, adding the plate count agar (Merck) to form a film layer afterwards and finally inoculating the bacteria. The Escherichia coli (E. coli, ATCC 25922) bacteria were used as test bacteria with an initial concentration of $1.5 \times 10^{4} \mathrm{cfu} / \mathrm{mL}$. The incubation was performed at $37^{\circ} \mathrm{C}$ for 1 day and the growth of bacterial colonies was visually detected at the end of the incubation period. The materials on which the bacterial growth was not observed were specified as antibacterial.

2.3. Determination of the Silver Release. Two grams of antibacterial functionalized material was added to $200 \mathrm{~mL}$ distilled water and maintained for 30 days in order to identify the silver released. The suspensions were continuously stirred during this period and samples were collected. At the end of 30-day period the materials were dried at $80^{\circ} \mathrm{C}$ for 24 hours. The metal ion percentages of antibacterial functionalized materials were analyzed by energy dispersive X-ray spectroscopy (EDX Oxford Instruments and Zeiss EVO 50). The silver concentration of aqueous dispersions of clays was investigated by inductively coupled plasma optical emission spectroscopy (ICP-OES) (Varian 720). The samples were collected at intervals (6 hours, 2, 5, 10, 15, 20 and 30 days) filtered and analyzed by ICP-OES immediately according to EPA Method 2007.

\section{Results and Discussion}

The clay samples subjected to physical treatment were analyzed by EDX. The percentage weights of major elements $(\mathrm{O}$, $\mathrm{Si}, \mathrm{Al}$, and $\mathrm{Mg}$ ) that are present in the structure of clays are tabulated in Table 1. Trace amounts of other elements such as $\mathrm{Fe}, \mathrm{Na}$, and $\mathrm{Ca}$ were also detected. The amount of silver investigated in clays subjected to physical treatment is shown in Table 2, in terms of weight and atomic percentages. Kaolinite was concluded to have a weaker ion exchange capacity and adsorptivity compared to clinoptilolite and sepiolite; therefore lesser amount of silver was incorporated in kaolinite $(0.13 \mathrm{wt} \%)$. By means of physical treatment the more amounts of silver ions were incorporated into clinoptilolite $(0.65 \mathrm{wt} \%)$ which presented a better ion exchange capacity and even more were incorporated into sepiolite $(0.75 \mathrm{wt} \%)$ due to its high surface to volume ratio.

The EDX analysis results of chemically treated clays are tabulated in Table 3. The samples were detected to be loaded with approximately $1.5 \mathrm{wt} \%$ Phosphorus. The chemical treatment with phosphoric acid enabled the incorporation of the more amount of silver ions into the clay samples. Such increment may be related to the more amount of silver ions required to neutralize the excess negative charge generated by the ligand exchange of $\mathrm{OH}^{-}$ions on the clay surface by the diphosphate ions [16]. An increase in the amount of silver ions incorporated into kaolinite is apparent since it was investigated as $0.84 \mathrm{wt} \%$. Chemical treatment by 
TABLE 3: EDX analysis results of the chemically treated clays.

\begin{tabular}{lccccc}
\hline Carrier & $\begin{array}{c}\mathrm{O} \\
(\mathrm{wt} \%)\end{array}$ & $\begin{array}{c}\mathrm{Si} \\
(\mathrm{wt} \%)\end{array}$ & $\begin{array}{c}\mathrm{Al} \\
(\mathrm{wt} \%)\end{array}$ & $\begin{array}{c}\mathrm{Mg} \\
(\mathrm{wt} \%)\end{array}$ & $\begin{array}{c}\text { Others (i.e., } \mathrm{Ag} \text {, } \mathrm{Fe}, \mathrm{Na}, \mathrm{Ca}, \text { and P) } \\
(\mathrm{wt} \%)\end{array}$ \\
\hline Kaolinite & 59.89 & 17.62 & 16.33 & - & 6.16 \\
Clinoptilolite & 57.08 & 30.02 & 6.09 & 0.15 & 6.66 \\
Sepiolite & 58.27 & 21.01 & 0.15 & 14.55 & 6.02 \\
\hline
\end{tabular}

${ }^{*}$ Detailed analysis results are tabulated in Table 2.

TABLE 4: Residual silver in physically and chemically treated clays after exposure to water media.

\begin{tabular}{lcccc}
\hline \multirow{2}{*}{ Carrier } & \multicolumn{2}{c}{ Physical treatment } & \multicolumn{2}{c}{ Chemical treatment } \\
& Weight \% & Atomic \% & Weight \% & Atomic \% \\
\hline Kaolinite & 0.06 & 0.01 & 0.70 & 0.10 \\
Clinoptilolite & 0.26 & 0.04 & 0.54 & 0.10 \\
Sepiolite & 0.19 & 0.03 & 0.36 & 0.08 \\
\hline
\end{tabular}

phosphoric acid increased the amount of silver incorporated into clinoptilolite and sepiolite in a similar manner; however, such increment was found to be limited when compared with the case in kaolinite as can be seen in Table 2 .

The antibacterial function of clays was investigated by modified halo method. The growth of bacteria on the neat, physically treated, and chemically treated kaolinite is shown in Figures 1(a), 1(b), and 1(c), respectively. No E. coli growth was witnessed on or at the zone surrounding the clays chemically or physically treated whereas bacterial growth was observed on and at the surroundings of the untreated kaolinite. The antibacterial activities of physically and chemically treated clinoptilolite and sepiolite are shown in Figures 2 and 3, respectively. Bacterial growth observed visually for clinoptilolite and sepiolite was similar to that of kaolinite. Silver release from the clays which were not subjected to chemical treatment by phosphoric acid was expected to release a relative small portion of silver attached to their structure. The circular zone diameters measured for the physically treated antibacterial clays $(d=25-28 \mathrm{~mm})$ were greater than the circular zone diameters measured for the chemically treated antibacterial clays $(d=22-24 \mathrm{~mm})$. Thus, it was concluded that the desired antibacterial effect was provided by the chemically treated antibacterial by releasing necessary amount of silver ions whereas the same effect was provided by the physically treated antibacterial material by releasing excessive amount of silver ions.

The weight percentages of the silver remaining on the physically treated and chemically treated clays are shown in Table 4. For instance, $53.9 \mathrm{wt} \%$ of the silver in the physically treated kaolinite was released to water media whereas only $16.7 \mathrm{wt} \%$ of the silver in chemically treated kaolinite was released. In case of physically treated clinoptilolite, $60 \mathrm{wt} \%$ of the silver attached was released; however, $70 \mathrm{wt} \%$ of the silver in the chemically treated clinoptilolite remained. The amount of silver released from physically treated sepiolite (74.4 wt\%) was also higher than the chemically treated sepiolite $(54.4 \mathrm{wt} \%)$. From these results it is evident that lesser amount of silver ions was released from chemically treated clays. The underlying phenomena for their tendency to controlled release are that the diphosphate ions taken previously by ligand exchange followed by $\mathrm{Ag}^{+}$ions by ion exchange lead to the formation of less soluble silver containing phosphate compounds [16]. A more controlled release of silver provided by chemical treatment enables a long-term antibacterial activity preventing the risks posed by higher silver concentrations resulting from the sudden release. Following their 30-day exposure to water media, the major elements detected in the clays are tabulated in Tables 5 and 6 for physically treated clays and chemically treated clays, respectively.

The chemical treatment enhanced the incorporation of silver ions to kaolinite and prevented the release of silver ions at a greater extent compared to the sepiolite and clinoptilolite. Therefore the silver release from the kaolinite to the aqueous media was measured with respect to time by ICP-OES and the result graph is shown in Figure 4. The concentration of silver released from the clays chemically treated has been found to be lower at all intervals compared to the physically treated clays. For instance, after 20 days of exposure the concentration of silver released from the chemically treated kaolinite was less than $15 \mathrm{mg} / \mathrm{L}$ whereas the concentration of silver released from the physically treated kaolinite was greater than $35 \mathrm{mg} / \mathrm{L}$. No sudden release of silver has been observed for the chemically treated kaolinite whereas the sudden release of silver has been observed for the physically treated kaolinite at the first 6 hours of exposure.

\section{Conclusion}

Antibacterial materials were developed incorporating silver into natural clays (kaolinite, clinoptilolite, and sepiolite) by ion exchange and their antibacterial activities were identified. The phosphoric acid treatment applied as a final stage in the processing of antibacterial material enabled the incorporation of an increased amount of silver into the clay materials and the controlled release of silver from the materials. The antibacterial test results of the clays have shown their capacity to be used successfully as antimicrobial agents. Physically treated clays which released a greater amount of silver have not presented comparative advantages in terms of the prevention of bacterial growth. Furthermore the silver release to the aqueous media from the physically and chemically treated clay materials (kaolinite) was investigated with respect to time. Chemical treatment was concluded to be more efficient in terms of silver incorporation and longevity due to controlled release feature. Such clays with efficient antibacterial 
TABLE 5: EDX analysis results of the physically treated clays after 30 days of exposure to water media.

\begin{tabular}{lccccc}
\hline Carrier & $\mathrm{O}$ & $\mathrm{Si}$ & $\mathrm{Al}$ & $\mathrm{Mg}$ & $\begin{array}{c}\text { Others (i.e., } \mathrm{Ag}^{*}, \mathrm{Fe}, \mathrm{Na}, \text { and Ca) } \\
(\mathrm{wt} \%)\end{array}$ \\
\hline Kaolinite & 57.22 & 18.83 & 20.17 & 0.19 & 3.78 \\
Clinoptilolite & 59 & 16.08 & 18.90 & 0.17 & 6.08 \\
Sepiolite & 59.36 & 15.78 & 0.94 & 15.95 & 7.98 \\
\hline
\end{tabular}

* Detailed analysis results are tabulated in Table 4.

TABLE 6: EDX analysis results of the chemically treated clays after 30 days of exposure to water media.

\begin{tabular}{lccccc}
\hline Carrier & $\begin{array}{c}\mathrm{O} \\
(\mathrm{wt} \%)\end{array}$ & $\begin{array}{c}\mathrm{Si} \\
(\mathrm{wt} \%)\end{array}$ & $\begin{array}{c}\mathrm{Al} \\
(\mathrm{wt} \%)\end{array}$ & $\begin{array}{c}\mathrm{Mg} \\
(\mathrm{wt} \%)\end{array}$ & $\begin{array}{c}\text { Others (i.e., } \mathrm{Ag} \text {, } \mathrm{Fe}, \mathrm{Na}, \mathrm{Ca}, \text { and P) } \\
(\mathrm{wt} \%)\end{array}$ \\
\hline Kaolinite & 60.90 & 16.30 & 16.18 & 0.14 & 6.48 \\
Clinoptilolite & 55.11 & 16.53 & 22.01 & 0.11 & 6.24 \\
Sepiolite & 55.38 & 22.13 & 1.65 & 14.48 & 6.36 \\
\hline
\end{tabular}

${ }^{*}$ Detailed analysis results are tabulated in Table 4.
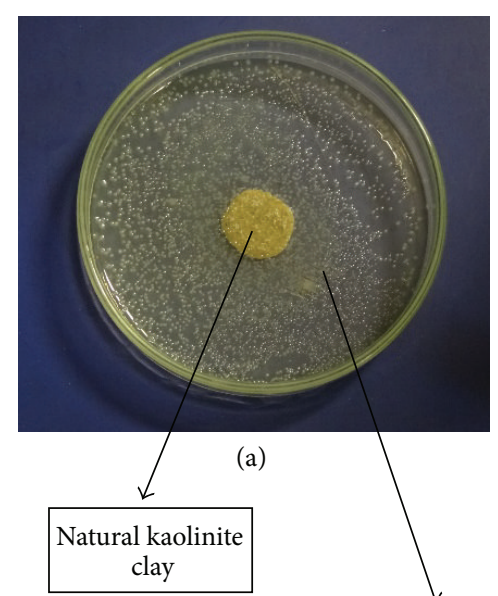

(a)

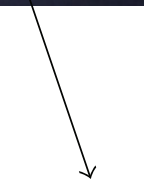

Bacteria colonies

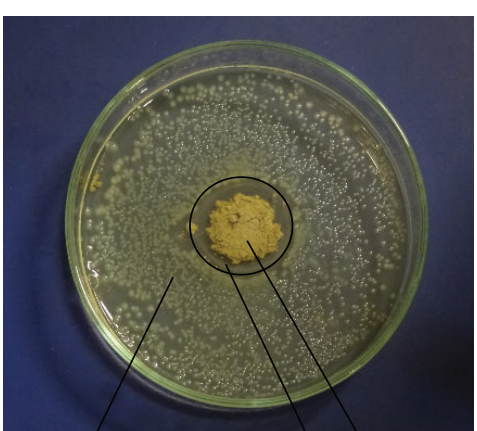

(b)

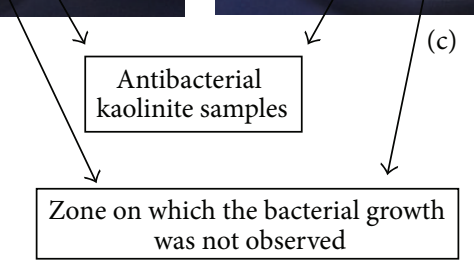

Figure 1: Antibacterial (modified halo) test results of the (a) neat, (b) physically treated, and (c) chemically treated kaolinite.

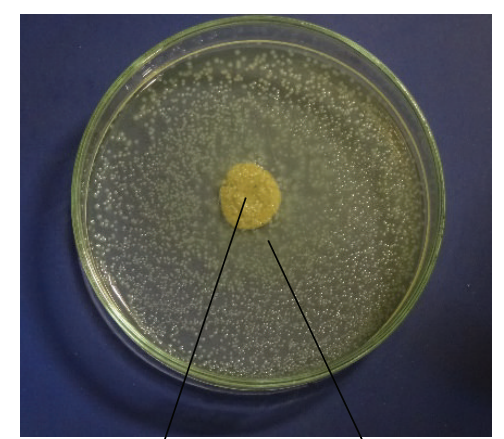

(a)

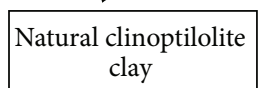
clay

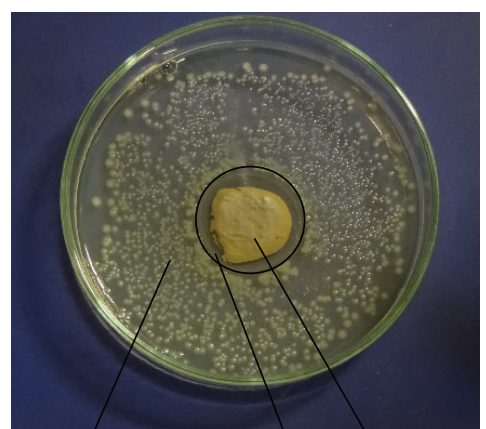

(b)

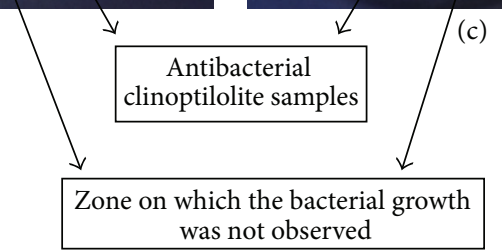

Figure 2: Antibacterial (modified halo) test results of the (a) neat, (b) physically treated, and (c) chemically treated clinoptilolite. 

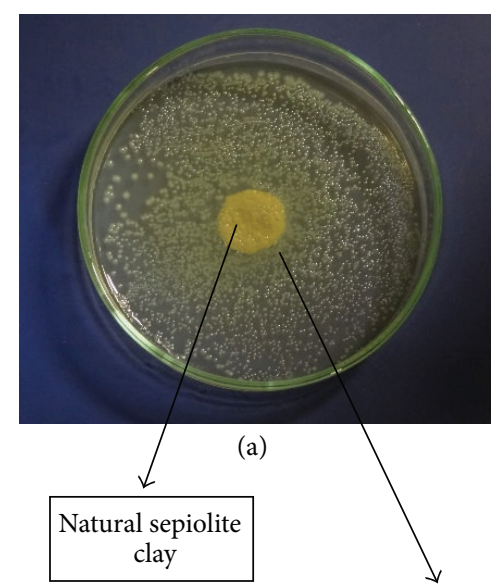

(a)

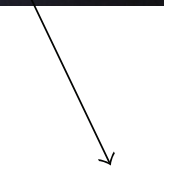

Bacteria colonies

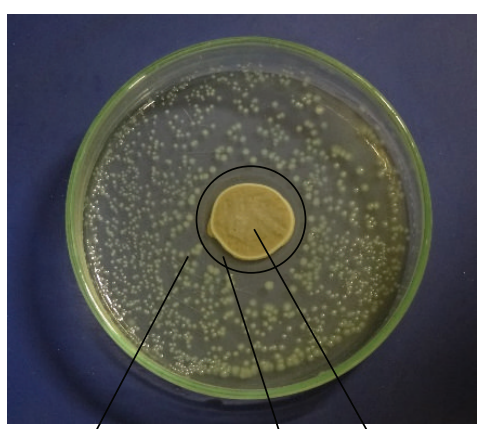

(b)

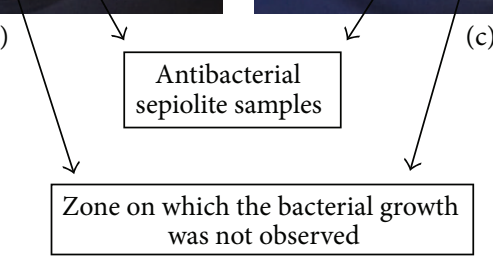

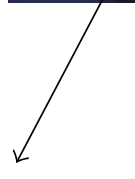

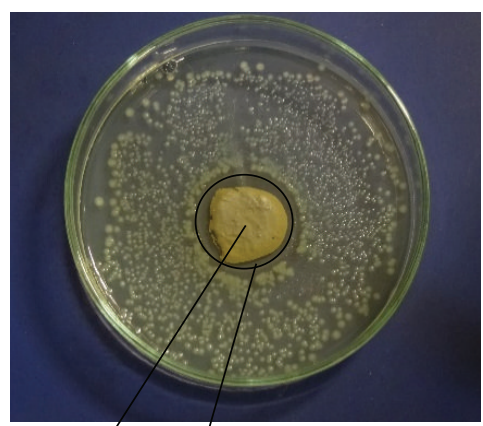

(c)

FIGURE 3: Antibacterial (modified halo) test results of the (a) neat, (b) physically treated, and (c) chemically treated sepiolite.

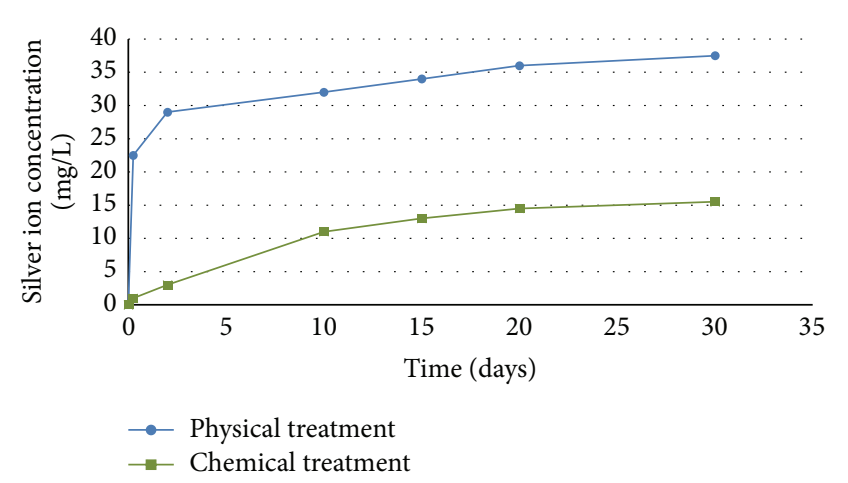

FIGURE 4: Concentration of silver released to aqueous media versus time plot for kaolinite.

properties were concluded to decrease the risks in terms of environment and human health resulting from overexposure and be cost-efficient alternatives to conventional antibacterial materials due to their controlled release mechanism.

\section{Conflict of Interests}

The authors declare that there is no conflict of interests regarding the publication of this paper.

\section{Acknowledgment}

This study was financially supported by Anadolu University, Scientific Research Projects Commission under Grant no. 050209.

\section{References}

[1] V. A. Oyanedel-Craver and J. A. Smith, "Sustainable colloidalsilver-impregnated ceramic filter for point-of-use water treatment," Environmental Science and Technology, vol. 42, no. 3, pp. 927-933, 2008.
[2] R. Pèrez-Tanoira, C. Pèrez-Jorge, J. L. Enduring et al., "Antibacterial properties of biomedical surfaces containing micrometric silver islands," Journal of Physics: Conference Series, vol. 252, no. 1, Article ID 012015, 8 pages, 2010.

[3] S. Kokura, O. Handa, T. Takagi, T. Ishikawa, Y. Naito, and T. Yoshikawa, "Silver nanoparticles as a safe preservative for use in cosmetics," Nanomedicine: Nanotechnology, Biology, and Medicine, vol. 6, no. 4, pp. 570-574, 2010.

[4] R. D. Holtz, B. A. Lima, A. G. Souza Filho, M. Brocchi, and O. L. Alves, "Nanostructured silver vanadate as a promising antibacterial additive to water-based paints," Nanomedicine: Nanotechnology, Biology, and Medicine, vol. 8, no. 6, pp. 935940, 2012.

[5] M. E. Üreyen, A. Doğan, and A. S. Koparal, "Antibacterial functionalization of cotton and polyester fabrics with a finishing agent based on silver-doped calcium phosphate powders," Textile Research Journal, vol. 82, no. 17, pp. 1731-1742, 2012.

[6] K. Malachová, P. Praus, Z. Rybková, and O. Kozák, "Antibacterial and antifungal activities of silver, copper and zinc montmorillonites," Applied Clay Science, vol. 53, no. 4, pp. 642-645, 2011.

[7] S. M. Magaña, P. Quintana, D. H. Aguilar et al., "Antibacterial activity of montmorillonites modified with silver," Journal of Molecular Catalysis A: Chemical, vol. 281, no. 1-2, pp. 192-199, 2008.

[8] A. Top and S. Ülkü, "Silver, zinc, and copper exchange in a Na-clinoptilolite and resulting effect on antibacterial activity," Applied Clay Science, vol. 27, no. 1-2, pp. 13-19, 2004.

[9] S. Chernousova and M. Epple, "Silver as antibacterial agent: ion, nanoparticle, and metal," Angewandte Chemie International Edition, vol. 52, no. 6, pp. 1636-1653, 2013.

[10] M. Valášková, M. Hundáková, K. Mamulová-Kutláková et al., "Preparation and characterization of antibacterial silver/vermiculites and silver/montmorillonites," Geochimica et Cosmochimica Acta, vol. 74, no. 22, pp. 6287-6300, 2010.

[11] M. Guzman, J. Dille, and S. Godet, "Synthesis and antibacterial activity of silver nanoparticles against gram-positive and gramnegative bacteria," Nanomedicine: Nanotechnology, Biology, and Medicine, vol. 8, no. 1, pp. 37-45, 2012. 
[12] C. Marambio-Jones and E. M. V. Hoek, "A review of the antibacterial effects of silver nanomaterials and potential implications for human health and the environment," Journal of Nanoparticle Research, vol. 12, no. 5, pp. 1531-1551, 2010.

[13] Y. Inoue, M. Hoshino, H. Takahashi et al., "Bactericidal activity of Ag-zeolite mediated by reactive oxygen species under aerated conditions," Journal of Inorganic Biochemistry, vol. 92, no. 1, pp. 37-42, 2002.

[14] N. R. Panyala, E. M. Peña-Méndez, and J. Havel, "Silver or silver nanoparticles: a hazardous threat to the environment and human health?" Journal of Applied Biomedicine, vol. 6, no. 3, pp. 117-129, 2008.

[15] H. He, D. Yang, P. Yuan, W. Shen, and R. L. Frost, "A novel organoclay with antibacterial activity prepared from montmorillonite and Chlorhexidini Acetas," Journal of Colloid and Interface Science, vol. 297, no. 1, pp. 235-243, 2006.

[16] Y. Onodera, T. Iwasaki, A. Chatterjee et al., "Bactericidal allophanic materials prepared from allophane soil I. Preparation and characterization of silver/phosphorus-silver loaded allophanic specimens," Applied Clay Science, vol. 18, no. 3-4, pp. 123-134, 2001. 

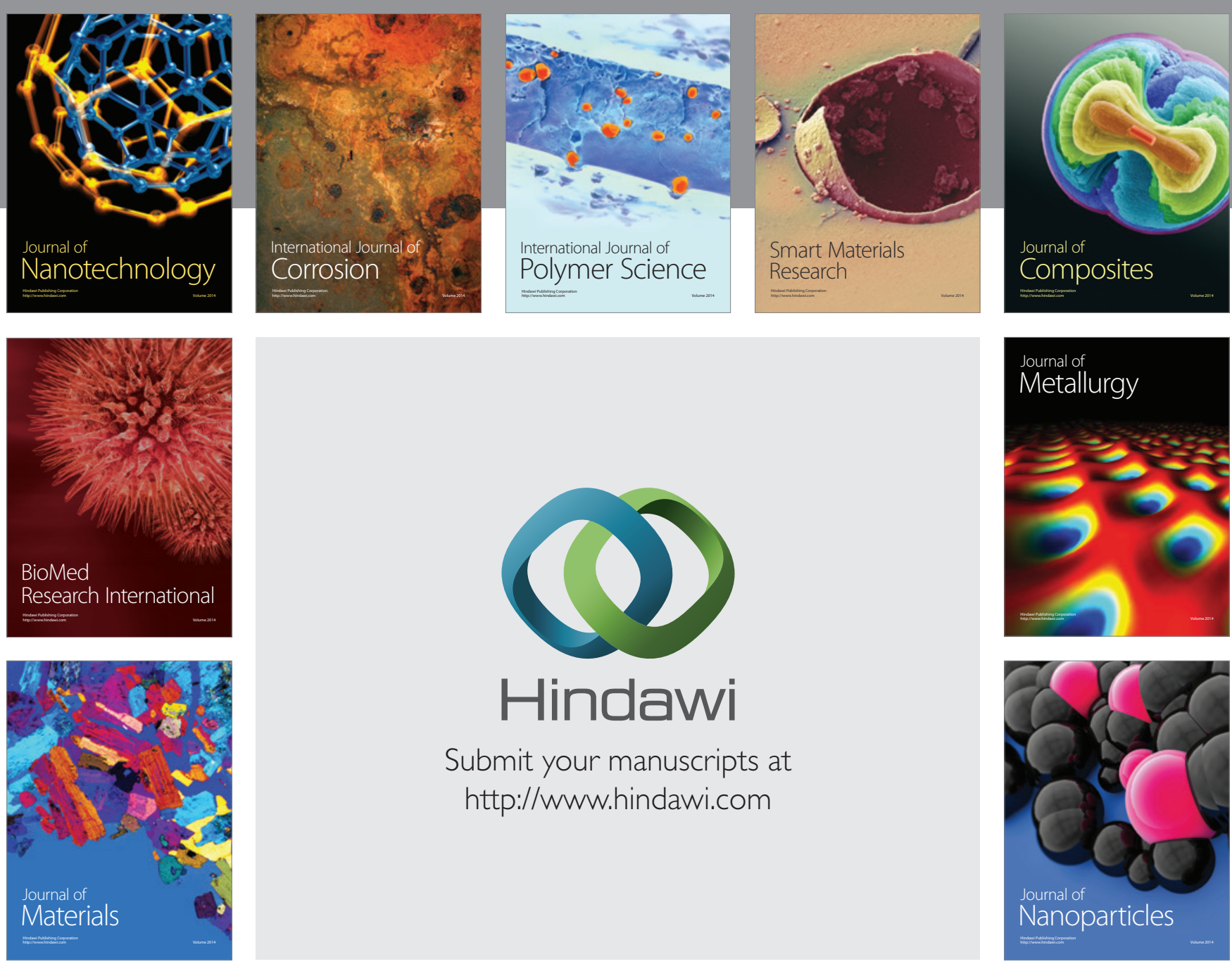

Submit your manuscripts at http://www.hindawi.com
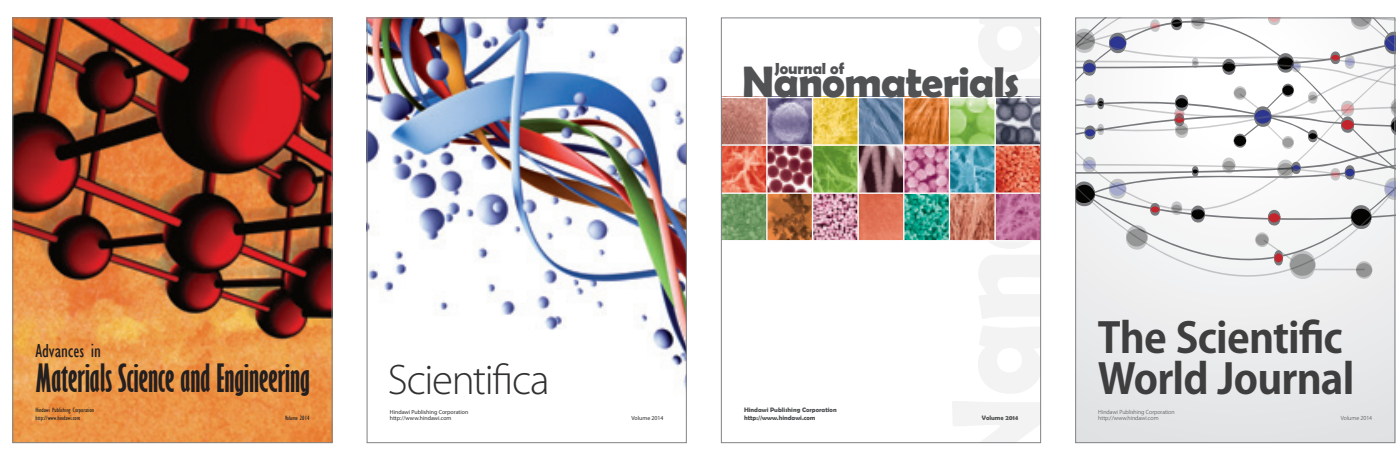

\section{The Scientific World Journal}
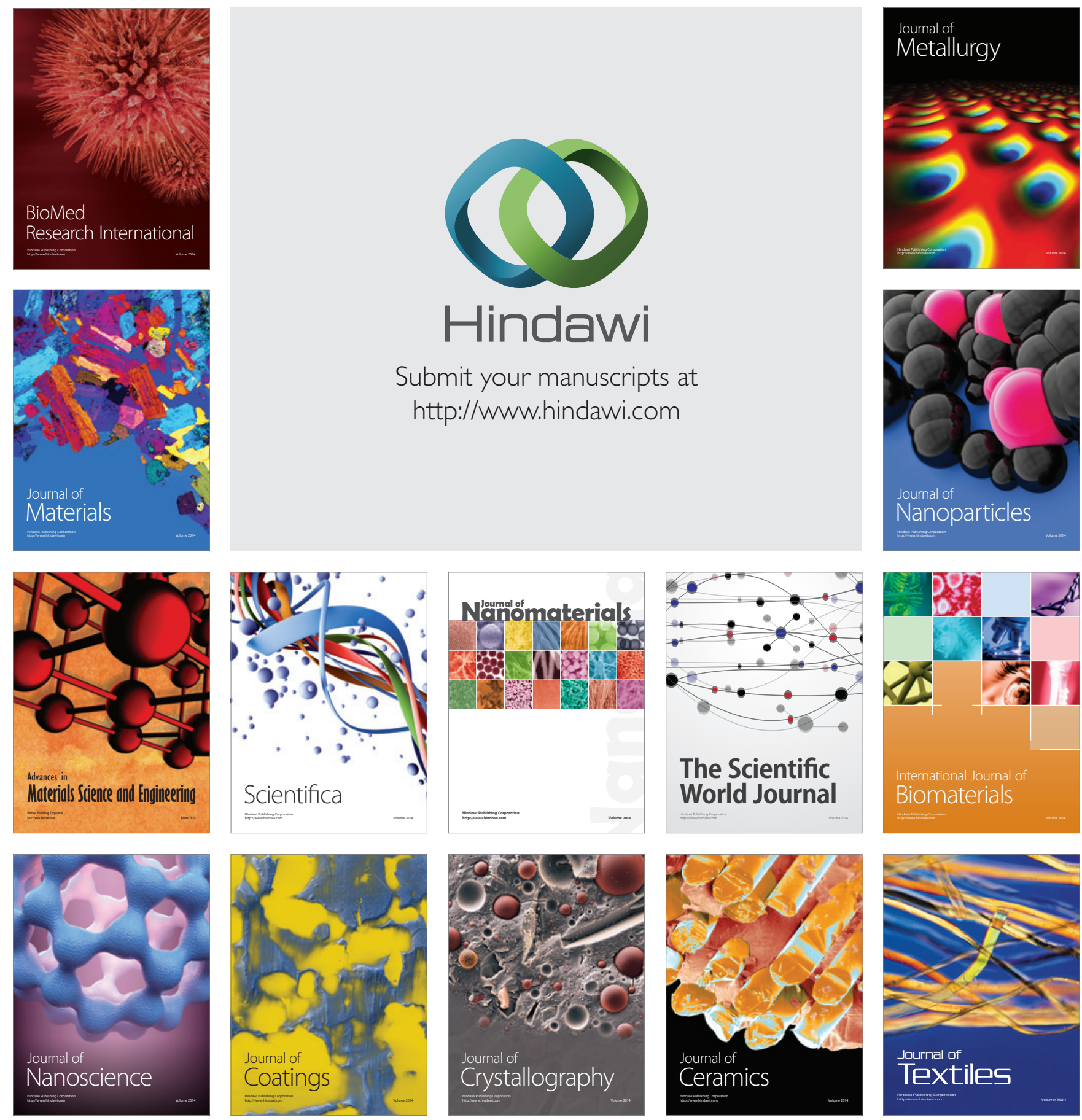